\title{
EFFECT OF A FERMENTED MIXTURE OF PAPAYA LEAF AND SEED MEAL ON PRODUCTION TRAITS AND INTESTINAL ECOLOGY OF THE INDONESIAN INDIGENOUS CROSSBRED CHICKENS
}

\author{
Sugiharto Sugiharto ${ }^{1}$, Endang Widiastuti ${ }^{1}$, Isroli Isroli ${ }^{1}$, \\ Hanny Indrat Wahyuni ${ }^{1}$, Turrini Yudiarti ${ }^{1}$

\footnotetext{
${ }^{1}$ Department of Animal Science, Faculty of Animal and Agricultural Sciences, Diponegoro University, Semarang, Central Java, Indonesia (50275)
}

Link to this article: https://doi.org/10.11118/actaun202068040707

Received: 5. 5. 2020, Accepted: 7. 7. 2020

To cite this article: SUGIHARTO SUGIHARTO, WIDIASTUTI ENDANG, ISROLI ISROLI, WAHYUNI HANNY INDRAT, YUDIARTI TURRINI. 2020. Effect of a Fermented Mixture of Papaya Leaf and Seed Meal on Production Traits and Intestinal Ecology of the Indonesian Indigenous Crossbred Chickens. Acta Universitatis Agriculturae et Silviculturae Mendelianae Brunensis, 68(4): 707-718.

\begin{abstract}
The work investigated the impact of a fermented mixture of papaya leaf and seed meal (FERM) on production traits, biochemical indices, intestinal ecology and carcass proportion of the Indonesian indigenous crossbred chickens (ICC). A 300 day-old ICC were assigned to five groups and fed on starter (1-4 weeks) and finisher diets (5-8 weeks) containing corn, soybean (CONT) or diets containing 1\% (FERM1), 2.5\% (FERM25), 5\% (FERM5) or 7.5\% (FERM75) of FERM. On week 8, blood was collected from birds prior to slaughter. The increased levels of FERM linearly reduced $(P<0.05)$ feed conversion and feed cost per kg weight gain, and increased $(P<0.05)$ income over feed cost of chickens. The relative weight of proventriculus linearly reduced $(P<0.05)$ with the enhanced contents of dietary FERM. The haemoglobin, erythrocytes and haematocrit values linearly reduced $(P<0.05)$ as the proportions of FERM enhanced. The mean corpuscular hemoglobin (MCH) levels were greater $(P<0.05)$ in FERM1 and FERM25 than that in control. The number of heterophils was greater $(P<0.05)$ in FERM1 than that in FERM25 and FERM5, but was not distinct from CONT and FERM75. The increased levels of FERM linearly increased $(P<0.05)$ thrombocytes values. Feeding FERM at $2.5 \%$ resulted in higher $(P<0.05)$ high-density lipoprotein (HDL) to low-density lipoprotein (LDL) ratio than that of control and FERM1. FERM reduced $(P<0.05)$ serum content of alanine aminotransferase (ALT). FERM75 had higher $(P<0.05)$ level of creatinine than control, FERM1 and FERM25. In duodenum, the increased levels of FERM linearly $(P<0.05)$ increased crypt depth $(C D)$. At 7.5\%, FERM reduced $(P<0.05) \mathrm{CD}$ and enhanced $(P<0.05)$ villus height $(\mathrm{VH})$ to $\mathrm{CD}$ ratio in jejunum. In ileum, $\mathrm{CD}$ linearly elevated $(P<0.05)$ with the increased FERM, while feeding $2.5 \%$ FERM enhanced $(P<0.05) \mathrm{VH}$ and $\mathrm{VH}$ to $\mathrm{CD}$ ratio. In conclusion, FERM was beneficial in improving economic performance, immune responses, physiological condition and intestinal morphology of ICC.
\end{abstract}

Keywords: crossbred chicken, fermented feed, papaya leaf, papaya seed

\section{INTRODUCTION}

In the recent decades, the ICC has received more attention from the market due to the unique taste of the meat. To reach the harvested weight $(700$ to $850 \mathrm{~g}$ ), the chicken must be raised intensively for 60 to 70 days (Sugiharto et al., 2018a). In-feed antibiotics have conventionally been incorporated in the production of ICC. However, controversy 
has become apparent particularly in relation to the phenomenon of antibiotic-resistant bacteria (Sugiharto and Ranjitkar, 2019). Owing to this concern, the administration of in-feed antibiotics as growth booster and antibacterial intermediary has, therefore, been globally prohibited.

A various alternatives have been offered to alter the role of in-feed antibiotics in poultry production including probiotics, prebiotic, enzymes and fermented feed (Meneses et al., 2016; Sugiharto and Ranjitkar, 2019). Also, phytobiotics have recently attracted more considerable attention among the poultry nutritionists. Of the types of phytobiotics, papaya (Carica papaya L.) leaf as well as seed have been demonstrated to possess pharmacological properties (Baskaran et al., 2012; Maisarah et al., 2013; Peter et al., 2014), and are thereby widely used in human traditional and alternative medicine. In poultry, the leaf and seed of papaya were incorporated in diets as protein supplements as well as phytogenic feed additives to promote the growth and well-being of birds (Bolu et al., 2009; Nideou et al., 2017; Onyimonyi and Ernest, 2009). Nonetheless, the efficacy of papaya leaf or seed as the substitute for in-feed antibiotic for poultry has largely been inconsistent (Agboola et al., 2018; Yang et al., 2015). Several factors may account for such inconsistency including the large content of fibre and the presences of anti-nutritive (such as tannin, phytic acid and oxalate) and toxic compounds in papaya leaf and seed (Adesuyi and Ipinmoroti, 2011; Halim et al., 2011). Note that the anti-nutritive factors may limit the utilization of nutrients as well as bioactive compounds in the papaya leaf and seed by the chicks (Adesuyi and Ipinmoroti, 2011). Hence, attempt is highly needed to improve the nutritive and phytogenic properties of papaya leaf and seed meal.

Besides improving the nutritional quality, fermentation has been demonstrated to decrease the contents of anti-nutritive and toxic compounds in feeds. Fermentation may also increase the functional properties, such as antimicrobial compounds, antioxidants and growth-promoting substances, in the substrates that are beneficially impact on the health and growth of chickens (Sugiharto and Ranjitkar, 2019). With regard to phytobiotics, a number of studies have documented the usefulness of fermentation for improving the bioactivity and efficacy of phytobiotic materials (e.g., Astragalus, Rehmannia glutinosa, Scutellaria Baicalensis and Gynura procumbens) as antibiotic alternatives for chickens (Jeong and Kim, 2015; Park et al., 2016; Qiao et al., 2018). Yet, study assessing the impact of fermentation on the functional effects of papaya leaf and seed meal on poultry has not ever been published.

With aim to gain advantage from the growthpromoting and pharmacological effects from both phytobiotic materials, the papaya leaf and seed meal were mixed prior to fermentation. In respect to fermentation starter, the filamentous fungus Chrysonilia crassa was selected given that the fungus possesses not only nutritional-improving effect, but has probiotic and antioxidant properties (Sugiharto et al., 2018b). Hence, C. crassa-fermentation was expected to corroborate the bioactivity and functional properties of papaya leaf and seed meal as the alternative protein-rich feedstuff as well as the substitute for in-feed antibiotics for the ICC. The current study addressed the influence of feeding FERM on production traits, biochemical indices, intestinal ecology and carcass characteristics of the ICC.

\section{MATERIALS AND METHODS}

\section{Preparation of Fermentation Starter}

Pure isolate of the fungus $C$. crassa was firstly rejuvenated from the stock of fungal culture (nurtured on potato dextrose agar [PDA] and stored at $4^{\circ} \mathrm{C}$ ) and then aerobically re-grown on PDA for $48 \mathrm{~h}$ at $38^{\circ} \mathrm{C}$. The fungal spores were collected with $10 \mathrm{~mL}$ autoclaved distilled water. To prepare the fermentation starter, the used rice (100 g) purchased from the traditional market in Semarang was cleaned and soaked in water for $1 \mathrm{~h}$. The cleaned rice was then steamed $(1 \mathrm{~h})$ and placed on trays until cool. The steamed used rice was subsequently inoculated with the spore suspension (10 mL) as formerly described. The inoculated culture was aerobically incubated at room temperature for $48 \mathrm{~h}$. It was then sun-dried, milled and sieved. Sample was obtained for the enumeration of the fungal colonies, and the rest was used as fermentation starter. According to the plate count method, the fermentation starter contained $>1 \times 10^{8} \mathrm{cfu} / \mathrm{g}$ of C. crassa.

\section{Production of FERM}

The leaves of papaya were collected from the gardens surrounding the university. The collected leaves were air-dried at room temperature, milled and placed at room temperature before use. Papaya seed was obtained from the fruit vendors around the university. The seed was cleaned (using water) from the papaya flesh and any debris and then sun-dried. The dried papaya seed was milled and stored at room temperature until use. To produce the FERM, the papaya leaf meal (500 g), the papaya seed meal (450 g) and the fermentation starter ( $50 \mathrm{~g}$ ) were entirely mixed. The sterilized water was poured to the mixture $(1: 1)$ to achieve the moisture content of the culture of about $40 \%$ (to perform the solid state fermentation). Afterward, the inoculated mixture was aerobically incubated at room temperature. After four days of incubation, the fermented product was sun-dried. For the in vivo experiment, the FERM was made in several batches with similar procedures/protocols for each batch. Sample was obtained from each batch of FERM production and then pooled for analysis of 
proximate (AOAC, 1995) and the remainder of the product was placed at room temperature until use for chicken trial. Data on the chemical compositions of leaf and seed meal of papaya and FERM are listed in Tab. I.

\section{In Vivo Experiment}

Three hundred day-old ICC were used in the current chicken trial. The ICC was the crossbred descent of the indigenous rooster from Indonesia and commercial laying hen (Isa Brown). The birds were weighed on arrival and placed to one of five diet categories, i.e., maize-soybean-based diet (control) and diets containing 1, 2.5, 5 or $7.5 \%$ of the FERM. Each dietary group composed of 60 chicks (six replicates with 10 chicks in each). The feed (in mash form) were prepared for starter (Tab. II) and finisher phases (Tab. III), and offered ad libitum to entire chicks. The birds were vaccinated on days 4, 14 and 22 using the combined Newcastleinfectious bursal diseases (ND-IBD), IBD and ND vaccines. Consumption of feed, live weight and feed conversion ratio (FCR) were quantified each week. Feed cost per $\mathrm{kg}$ weight gain and

I: Proximate compositions of papaya leaf and seed meal and fermented mixture of papaya leaf and seed meal ${ }^{1}$

\begin{tabular}{lccc}
\hline Items (\%, dry matter basis) & Papaya leaf meal & Papaya seed meal & FERM \\
\hline Dry matter & 87.6 & 88.2 & 86.7 \\
Crude protein & 26.7 & 24.4 & 29.1 \\
Crude fat & 6.48 & 11.9 & 5.96 \\
Crude fibre & 34.2 & 23.6 & 18.5 \\
Crude ash & 13.8 & 8.96 & 10.8 \\
\hline
\end{tabular}

${ }^{1}$ Analysis was conducted in duplicate

FERM: fermented mixture of papaya leaf and seed meal

II: Ingredients and nutrient compositions of starter feeds (week 1 to 4)

\begin{tabular}{lccccc}
\hline \multirow{2}{*}{ Items (\%, unless otherwise noted) } & \multicolumn{5}{c}{ Dietary groups } \\
\cline { 2 - 5 } Yellow maize & CONT & FERM1 & FERM25 & FERM5 & FERM75 \\
SBM & 55.0 & 54.7 & 54.2 & 53.5 & 53.0 \\
MBM & 35.8 & 35.2 & 34.5 & 33.5 & 33.0 \\
Soybean oil & 4.50 & 4.50 & 4.15 & 3.55 & 2.25 \\
FERM & 1.50 & 1.45 & 1.40 & 1.25 & 1.00 \\
DL-methionine, 990 g & - & 1.00 & 2.50 & 5.00 & 7.50 \\
L-Lysine, 780 g & 0.30 & 0.30 & 0.30 & 0.30 & 0.30 \\
Limestone & 0.20 & 0.20 & 0.20 & 0.20 & 0.20 \\
DCP & 0.50 & 0.50 & 0.50 & 0.50 & 0.50 \\
Premix ${ }^{1}$ & 1.50 & 1.50 & 1.50 & 1.50 & 1.50 \\
Salt & 0.50 & 0.50 & 0.50 & 0.50 & 0.50 \\
\hline & 0.25 & 0.25 & 0.25 & 0.25 & 0.25 \\
\hline ME ${ }^{2}$ (kcal/kg) & \multicolumn{7}{c}{ Calculated compositions } & & \\
Crude protein & 2,900 & 2,900 & 2,903 & 2,904 & 2,902 \\
Crude fibre & 22.0 & 22.0 & 22.0 & 22.0 & 22.0 \\
Cost of feed (IDR/kg) & 5.60 & 5.70 & 5.80 & 6.10 & 6.40 \\
\hline
\end{tabular}

${ }^{1}$ Premix contained (per kg of diet) of vitamin A 7,750 IU, vitamin D3 1,550 IU, vitamin E $1.88 \mathrm{mg}$, vitamin B1 $1.25 \mathrm{mg}$, vitamin B2 $3.13 \mathrm{mg}$, vitamin B6 $1.88 \mathrm{mg}$, vitamin B12 $0.01 \mathrm{mg}$, vitamin C $25 \mathrm{mg}$, folic acid $1.50 \mathrm{mg}$, Ca-d-pantothenate $7.5 \mathrm{mg}$, niacin $1.88 \mathrm{mg}$, biotin $0.13 \mathrm{mg}$, BHT $25 \mathrm{mg}$, Co $0.20 \mathrm{mg}$, Cu $4.35 \mathrm{mg}$, Fe $54 \mathrm{mg}$, I $0.45 \mathrm{mg}$, Mn $130 \mathrm{mg}$, Zn $86.5 \mathrm{mg}$, Se $0.25 \mathrm{mg}$, L-lysine $80 \mathrm{mg}$, Choline chloride $500 \mathrm{mg}$, DL-methionine $900 \mathrm{mg}$, CaCO3 $641.5 \mathrm{mg}$, DCP $1500 \mathrm{mg}$

2ME was determined based on formula (Bolton, 1967) as follow: 40.81 \{0.87 [crude protein +2.25 crude fat + nitrogenfree extract] +2.5$\}$

CONT: corn-soybean-based diet (control diet), FERM1: diet containing 1\% FERM, FERM25: 2.5\% FERM, FERM5: 5\% FERM, FERM75: 7.5\% FERM, SBM: soybean meal, MBM: meat bone meal, FERM: fermented mixture of papaya leaf and seed meal, DCP: dicalcium phosphate, ME: metabolizable energy 
III: Ingredients and nutrient compositions of finisher feeds (week 5 to 8)

\begin{tabular}{|c|c|c|c|c|c|}
\hline \multirow{2}{*}{ Items ( $\%$, unless otherwise noted) } & \multicolumn{5}{|c|}{ Dietary groups } \\
\hline & CONT & FERM1 & FERM25 & FERM5 & FERM75 \\
\hline Yellow maize & 60.0 & 59.8 & 59.3 & 58.6 & 58.0 \\
\hline SBM & 32.0 & 31.5 & 30.7 & 29.7 & 28.3 \\
\hline MBM & 2.65 & 2.50 & 2.35 & 1.65 & 1.40 \\
\hline Soybean oil & 2.10 & 2.00 & 1.95 & 1.80 & 1.57 \\
\hline FERM & - & 1.00 & 2.50 & 5.00 & 7.50 \\
\hline DL-methionine, $990 \mathrm{~g}$ & 0.30 & 0.30 & 0.30 & 0.30 & 0.30 \\
\hline L-Lysine, $780 \mathrm{~g}$ & 0.20 & 0.20 & 0.20 & 0.20 & 0.20 \\
\hline Limestone & 0.50 & 0.50 & 0.50 & 0.50 & 0.50 \\
\hline DCP & 1.50 & 1.50 & 1.50 & 1.50 & 1.50 \\
\hline Premix $^{1}$ & 0.50 & 0.50 & 0.50 & 0.50 & 0.50 \\
\hline Salt & 0.25 & 0.25 & 0.25 & 0.25 & 0.25 \\
\hline \multicolumn{6}{|c|}{ Calculated compositions } \\
\hline $\mathrm{ME}^{2}(\mathrm{kcal} / \mathrm{kg})$ & 3,001 & 2,999 & 3,001 & 3,003 & 2,999 \\
\hline Crude protein & 20.0 & 20.0 & 20.0 & 20.0 & 19.9 \\
\hline Crude fibre & 5.60 & 5.70 & 5.90 & 6.10 & 6.40 \\
\hline Cost of feed (IDR/kg) & 6,839 & 6,751 & 6,657 & 6,465 & 6,254 \\
\hline
\end{tabular}

${ }^{1}$ Premix contained (per kg of diet) of vitamin A 7,750 IU, vitamin D3 1,550 IU, vitamin E $1.88 \mathrm{mg}$, vitamin B1 $1.25 \mathrm{mg}$, vitamin B2 $3.13 \mathrm{mg}$, vitamin B6 $1.88 \mathrm{mg}$, vitamin B12 $0.01 \mathrm{mg}$, vitamin C $25 \mathrm{mg}$, folic acid $1.50 \mathrm{mg}$, Ca-d-pantothenate $7.5 \mathrm{mg}$, niacin $1.88 \mathrm{mg}$, biotin $0.13 \mathrm{mg}$, BHT $25 \mathrm{mg}$, Co $0.20 \mathrm{mg}$, Cu $4.35 \mathrm{mg}$, Fe $54 \mathrm{mg}$, I $0.45 \mathrm{mg}$, Mn $130 \mathrm{mg}$, Zn $86.5 \mathrm{mg}$, Se $0.25 \mathrm{mg}$, L-lysine $80 \mathrm{mg}$, Choline chloride $500 \mathrm{mg}$, DL-methionine $900 \mathrm{mg}$, CaCO3 $641.5 \mathrm{mg}$, DCP 1,500 mg

2ME was determined based on formula (Bolton, 1967) as follow: 40.81 \{0.87 [crude protein + 2.25 crude fat + nitrogenfree extract] +2.5$\}$

CONT: corn-soybean-based diet (control diet), FERM1: diet containing 1\% FERM, FERM25: 2.5\% FERM, FERM5: 5\% FERM, FERM75: 7.5\% FERM, SBM: soybean meal, MBM: meat bone meal, FERM: fermented mixture of papaya leaf and seed meal, DCP: dicalcium phosphate, ME: metabolizable energy

income over feed cost were computed on week 8 according to Frempong et al. (2019). At week 8, one chick per replicate/pen (6 chicks per diet group) were randomly picked up and the blood was taken from the veins of wing. The obtained blood was then placed in vacutainers with ethylenediaminetetraacetic acid (EDTA) for the haematological measurement or in anticoagulantfree vacutainers to yield serum. Following blood collection, the chicks were slaughtered, the feather was removed and carcass yield was determined thereafter. Digesta from the ileum and caeca were collected in the sterile tube for microbiology assessment. About $2 \mathrm{~cm}$ of duodenal, jejunal and ileal segments were preserved in 10\% neutral formalin buffer solution for the measurement of intestinal morphology.

The haematological counts was assessed using a hematology analyzer (Prima Fully-auto Hematology Analyzer, PT. Prima Alkesindo Nusantara, Jakarta, Indonesia) as previously conducted by Sugiharto et al. (2018a). The serum titers of antibody toward Newcastle disease vaccine (NDV) were assessed using hemagglutination inhibition (HI) analysis based on Villegas (1987). The profile of lipid and the levels of creatinine and uric acid were analyzed based on the enzymatic colorimetric/colour test. The spectrophotometric/photometric test was exploited to measure the serum levels of albumin, protein, aspartate aminotransferase (AST) and alanine aminotransferase (ALT). The content of globulin in serum were considered from the total protein minus albumin. Serial biochemical analysis was performed following the producer's guidance (DiaSys Diagnostic System GmbH, Holzheim, Germany).

The histological assessment of the small intestine was carried out according to Tunç et al. (2019). To perform the analysis, $5 \mu \mathrm{m}$ of the intestinal slices were stained using hematoxylin and eosin. The optical microscope fitted to the digital camera was employed to measure the VH and CD. For each chick, the mean of $\mathrm{VH}$ and $\mathrm{CD}$ was obtained from the five measurements. The numbers of selected bacterial population in gut content were assigned following Sugiharto et al. (2018a). In brief, the counting of coliform and lactose-negative enterobacteria in the intestinal digesta were conducted on MacConkey agar (Merck KGaA, Darmstadt, Germany) as red and colourless colonies after being incubated aerobically $\left(24 \mathrm{~h}, 38^{\circ} \mathrm{C}\right)$. Enterobacteriaceae was the total of 
IV: Production traits of the Indonesian indigenous crossbred chicken fed treatment diets

\begin{tabular}{|c|c|c|c|c|c|c|c|c|}
\hline \multirow{2}{*}{ Items } & \multicolumn{5}{|c|}{ Dietary groups } & \multirow{2}{*}{ SE } & \multirow{2}{*}{$\begin{array}{l}P \text { value- } \\
\text { ANOVA }^{1}\end{array}$} & \multirow{2}{*}{$\begin{array}{l}P \text { value- } \\
\text { regression }\end{array}$} \\
\hline & CONT & FERM1 & FERM25 & FERM5 & FERM75 & & & \\
\hline Initial body weight (g) & 36.2 & 36.2 & 36.2 & 36.9 & 37.2 & 0.31 & 0.44 & 0.84 \\
\hline \multicolumn{9}{|c|}{ Week 1-4 } \\
\hline Weight gain (g) & 243 & 250 & 245 & 247 & 241 & 6.74 & 0.91 & 0.69 \\
\hline Cumulative FI (g) & $680^{\mathrm{a}}$ & $669^{a b}$ & $656^{\mathrm{ab}}$ & $646^{\mathrm{bc}}$ & $625^{c}$ & 9.50 & 0.01 & $<0.01$ \\
\hline FCR & 2.81 & 2.69 & 2.68 & 2.62 & 2.60 & 0.07 & 0.23 & 0.02 \\
\hline \multicolumn{9}{|c|}{ Week 5-8 } \\
\hline Weight gain (g) & 349 & 374 & 384 & 419 & 387 & 19.6 & 0.19 & 0.06 \\
\hline Cumulative FI (g) & 1,068 & 1,091 & 1,049 & 1,088 & 1,063 & 19.2 & 0.51 & 0.84 \\
\hline FCR & 3.09 & 2.99 & 2.74 & 2.64 & 2.77 & 0.15 & 0.22 & 0.04 \\
\hline \multicolumn{9}{|c|}{ Week 1-8 } \\
\hline Weight gain (g) & 592 & 624 & 630 & 666 & 628 & 19.2 & 0.15 & 0.08 \\
\hline Cumulative FI (g) & 1,747 & 1,759 & 1,704 & 1,734 & 1,688 & 23.1 & 0.19 & 0.06 \\
\hline FCR & 2.96 & 2.84 & 2.71 & 2.62 & 2.70 & 0.09 & 0.08 & 0.01 \\
\hline Feed cost per weight gain (IDR) ${ }^{3}$ & $20,118^{\mathrm{a}}$ & $19,110^{\mathrm{ab}}$ & $17,942^{\mathrm{bc}}$ & $16,854^{c}$ & $16,732^{c}$ & 584 & $<0.01$ & $<0.01$ \\
\hline Income over feed cost (IDR) ${ }^{4}$ & $7,612^{c}$ & $8,647^{\mathrm{bc}}$ & $9,354^{\mathrm{abc}}$ & $10,626^{a}$ & $10,136^{\mathrm{ab}}$ & 595 & 0.01 & $<0.01$ \\
\hline
\end{tabular}

a,b,c Means in the same row with various letters indicate notable differences $(\mathrm{P}<0.05)$

${ }^{1}$ Referes to analysis of variance (ANOVA)

${ }^{2}$ Referes to regression analysis

${ }^{3}$ Values were calculated at the time of study as the cost of feed consumed to achieve a kilogramme live weight gain

${ }^{4}$ Values were counted at the time of study as the total income minus total feed cost

CONT: corn-soybean-based diet, FERM1; diet containing 1\%, FERM25: diet containing 2.5\%, FERM5: diet containing 5\%, FERM75: diet containing $7.5 \%$ of the FERM, SE: standard error, FI: feed intake, FCR: feed conversion ratio, IDR: Indonesian Rupiah (Indonesian currency)

V: Selected internal organs relative weight of the Indonesian indigenous crossbred chicken fed treatment diets

\begin{tabular}{|c|c|c|c|c|c|c|c|c|}
\hline \multirow{2}{*}{ Items (\% live BW) } & \multicolumn{5}{|c|}{ Dietary groups } & \multirow{2}{*}{ SE } & \multirow{2}{*}{$\begin{array}{l}P \text { value- } \\
\text { ANOVA }^{1}\end{array}$} & \multirow{2}{*}{$\begin{array}{l}P \text { value- } \\
\text { regression }\end{array}$} \\
\hline & CONT & FERM1 & FERM25 & FERM5 & FERM75 & & & \\
\hline Heart & 0.47 & 0.51 & 0.50 & 0.50 & 0.50 & 0.02 & 0.81 & 0.57 \\
\hline Liver & 2.58 & 2.71 & 2.52 & 2.37 & 2.43 & 0.13 & 0.43 & 0.13 \\
\hline Proventriculus & 0.88 & 0.88 & 0.94 & 0.77 & 0.77 & 0.05 & 0.06 & 0.03 \\
\hline Gizzard & 3.27 & 2.95 & 3.06 & 2.82 & 2.88 & 0.19 & 0.52 & 0.14 \\
\hline Pancreas & 0.31 & 0.32 & 0.35 & 0.28 & 0.30 & 0.03 & 0.49 & 0.53 \\
\hline Duodenum & 0.83 & 0.97 & 0.90 & 0.74 & 0.87 & 0.08 & 0.40 & 0.57 \\
\hline Jejunum & 1.44 & 1.39 & 1.63 & 1.42 & 1.62 & 0.13 & 0.56 & 0.35 \\
\hline Ileum & 1.08 & 1.07 & 1.20 & 1.03 & 0.99 & 0.08 & 0.50 & 0.41 \\
\hline Caeca & 0.65 & 0.70 & 0.76 & 0.65 & 0.69 & 0.05 & 0.50 & 0.83 \\
\hline Spleen & 0.27 & 0.32 & 0.23 & 0.22 & 0.24 & 0.04 & 0.46 & 0.27 \\
\hline Thymus & 0.46 & 0.46 & 0.37 & 0.47 & 0.24 & 0.07 & 0.18 & 0.08 \\
\hline Bursa of Fabricius & 0.15 & 0.18 & 0.14 & 0.18 & 0.09 & 0.04 & 0.39 & 0.35 \\
\hline Abdominal fat & 0.17 & 0.26 & 0.08 & 0.26 & 0.04 & 0.09 & 0.28 & 0.39 \\
\hline
\end{tabular}

${ }^{1}$ Referes to analysis of variance (ANOVA)

${ }^{2}$ Referes to regression analysis

CONT: corn-soybean-based diet, FERM1; diet containing 1\%, FERM25: diet containing 2.5\%, FERM5: diet containing 5\%, FERM75: diet containing $7.5 \%$ of the FERM, BW: body weight, SE: standard error 
coliform plus lactose-negative enterobacteria. The numbers of lactic acid bacteria (LAB) were determined on de Man, Rogosa and Sharpe (MRS; Merck KGaA) agar after being incubated anaerobically ( $\left.48 \mathrm{~h}, 38^{\circ} \mathrm{C}\right)$.

The data were analysed using ANOVA (SAS Inst. Inc., Cary, NC, USA). When the notable $(P<0.05)$ impact of treatment existed, the data were then further analysed based on the Duncan's multiplerange test. The data were also subjected to linear regression analysis to see the influence of increasing FERM in the diets on the parameters measured.

\section{RESULTS}

\section{Proximate Composition of Papaya Leaf and Seed Meal and FERM}

Data on the proximate composition of papaya leaf meal, papaya seed meal and FERM are listed in Tab. I. Fermentation using the fungus C. crassa increased the crude protein and remarkably reduced the fibre fraction of papaya leaf and seed meal.

\section{Production Traits and Economic Performance of Chickens}

Data on the production and economic performances of the ICC are listed in Tab. IV. The increased levels of FERM linearly ameliorated $(P<0.05)$ feed consumption and FCR of chicks during week 1-4. During week 5-8 and 1-8, the increased dietary contents of FERM linearly improved $(P<0.05)$ FCR of chicks. Throughout the study period (week 1-8), feed cost per $\mathrm{kg}$ weight gain and income over feed cost linearly reduced $(P<0.05)$ and enhanced $(P<0.05)$ with the elevated dietary proportions of FERM.

\section{Internal Organs Relative Weight of Chickens}

ANOVA test showed an absent influence $(P>0.05)$ of FERM on internal organs of ICC (Tab. V). Yet, regression analysis showed that proventriculus weight linearly reduced $(P<0.05)$ with the raised contents of FERM.

\section{Complete Blood Counts and Serum Biochemistry of Chickens}

Tab. VI presents the haematological profile of the ICC fed treatment diets. The levels of erythrocytes, haemoglobin and haematocrit linearly reduced $(P<0.05)$ with the enhanced concentrations of FERM in diets. The values of mean corpuscular haemoglobin $(\mathrm{MCH})$ were higher $(P<0.05)$ in FERM1 and FERM25 than that in control. The number of heterophils was greater $(P<0.05)$ in FERM1 than that in FERM25 and FERM5, but was not distinct $(P>0.05)$ from CONT and FERM75. The elevated proportions of FERM linearly raised $(P<0.05)$ thrombocytes values.

The biochemical indices of serum and antibody titers toward NDV are shown in Tab. VII. Feeding FERM at $2.5 \%$ resulted in higher $(P<0.05)$ HDL to LDL ratio than that of control and FERM1. FERM5 and FERM75 were intermediate. Dietary inclusion of FERM alleviated $(P<0.05)$ serum ALT level. FERM75 had greater $(P<0.05)$ concentration of creatinine than CONT, FERM1 and FERM25. FERM5 was intermediary.

\section{Selected Bacteria Populations and} Morphology of the Intestine of Chickens

The numbers of bacteria in the intestine of ICC are listed on Tab. VIII. The diets showed an absent influence $(P>0.05)$ on the bacteria counts in the ileal and caecal digesta of the crossbred chickens.

VI: Complete blood counts of the Indonesian indigenous crossbred chicken fed treatment diets

\begin{tabular}{|c|c|c|c|c|c|c|c|c|}
\hline \multirow{2}{*}{ Items } & \multicolumn{5}{|c|}{ Dietary groups } & \multirow{2}{*}{ SE } & \multirow{2}{*}{$\begin{array}{l}P \text { value- } \\
\text { ANOVA }^{1}\end{array}$} & \multirow{2}{*}{$\begin{array}{l}P \text { value- } \\
\text { regression }{ }^{2}\end{array}$} \\
\hline & CONT & FERM1 & FERM25 & FERM5 & FERM75 & & & \\
\hline Hemoglobin (g/dL) & 10.6 & 10.5 & 9.92 & 9.75 & 9.42 & 0.48 & 0.39 & 0.04 \\
\hline Erythrocytes $\left(10^{6} / \mu \mathrm{L}\right)$ & 3.32 & 3.03 & 2.81 & 2.88 & 2.86 & 0.15 & 0.15 & 0.03 \\
\hline Hematocrit (\%) & 40.4 & 36.8 & 33.7 & 35.3 & 34.0 & 1.88 & 0.11 & 0.02 \\
\hline MCV (fl) & 123 & 122 & 121 & 123 & 120 & 1.23 & 0.29 & 0.30 \\
\hline MCH (pg) & $32.0^{c}$ & $34.6^{\mathrm{ab}}$ & $35.3^{\mathrm{a}}$ & $33.8^{\mathrm{abc}}$ & $33.0^{\mathrm{bc}}$ & 0.70 & 0.02 & 0.65 \\
\hline MCHC (g/dL) & 26.2 & 28.5 & 29.4 & 27.5 & 31.1 & 1.70 & 0.36 & 0.11 \\
\hline Leukocytes $\left(10^{3} / \mu \mathrm{L}\right)$ & 65.4 & 58.3 & 54.5 & 57.0 & 57.7 & 3.80 & 0.35 & 0.17 \\
\hline Heterophils $\left(10^{3} / \mu \mathrm{L}\right)$ & $1.75^{\mathrm{abc}}$ & $2.50^{\mathrm{a}}$ & $1.25^{c}$ & $1.58^{\mathrm{bc}}$ & $2.25^{\mathrm{ab}}$ & 0.28 & 0.02 & 0.93 \\
\hline Lymphocytes $\left(10^{3} / \mu \mathrm{L}\right)$ & 63.7 & 55.8 & 53.3 & 55.4 & 55.4 & 3.79 & 0.37 & 0.17 \\
\hline Thrombocytes $\left(10^{3} / \mu \mathrm{L}\right)$ & $13.8^{\mathrm{d}}$ & $17.5^{\mathrm{c}}$ & $23.7^{b}$ & $21.0^{\mathrm{b}}$ & $26.8^{\mathrm{a}}$ & 1.06 & $<0.01$ & $<0.01$ \\
\hline
\end{tabular}

a,b,c Means in the same row with various letters indicate notable differences $(P<0.05)$

${ }^{1}$ Referes to analysis of variance (ANOVA)

${ }^{2}$ Referes to regression analysis

CONT: corn-soybean-based diet, FERM1; diet containing 1\%, FERM25: diet containing 2.5\%, FERM5: diet containing 5\%, FERM75: diet containing 7.5\% of the FERM, SE: standard error, MCV: mean corpuscular volume, MCH: mean corpuscular hemoglobin, MCHC: mean corpuscular hemoglobin concentration 
VII: Serum biochemical indices and antibody titer toward Newcastle disease vaccine of the Indonesian indigenous crossbred chicken fed treatment diets

\begin{tabular}{|c|c|c|c|c|c|c|c|c|}
\hline \multirow{2}{*}{ Items } & \multicolumn{5}{|c|}{ Dietary groups } & \multirow{2}{*}{ SE } & \multirow{2}{*}{$\begin{array}{l}P \text { value- } \\
\text { ANOVA }^{1}\end{array}$} & \multirow{2}{*}{$\begin{array}{l}P \text { value- } \\
\text { regression }\end{array}$} \\
\hline & CONT & FERM1 & FERM25 & FERM5 & FERM75 & & & \\
\hline Total triglyceride (mg/dL) & 63.3 & 58.8 & 54.6 & 57.8 & 45.1 & 8.10 & 0.59 & 0.13 \\
\hline Total cholesterol (mg/dL) & 107 & 113 & 111 & 119 & 107 & 7.48 & 0.75 & 0.77 \\
\hline LDL (mg/dL) & 13.0 & 24.3 & 1.53 & 17.3 & 10.7 & 5.85 & 0.11 & 0.60 \\
\hline HDL (mg/dL) & 76.0 & 77.0 & 116 & 112 & 101 & 12.9 & 0.07 & 0.08 \\
\hline HDL/LDL ratio & $17.5^{\mathrm{b}}$ & $4.30^{\mathrm{b}}$ & $101^{\mathrm{a}}$ & $73.4^{\mathrm{ab}}$ & $64.7^{\mathrm{ab}}$ & 22.0 & 0.02 & 0.04 \\
\hline Total protein $(\mathrm{g} / \mathrm{dL})$ & 7.01 & 5.73 & 8.58 & 4.95 & 5.66 & 1.27 & 0.24 & 0.53 \\
\hline Albumin (g/dL) & 1.46 & 1.49 & 1.52 & 1.57 & 1.49 & 0.05 & 0.70 & 0.45 \\
\hline Globulin (g/dL) & 5.55 & 4.24 & 7.01 & 3.41 & 4.17 & 1.26 & 0.23 & 0.53 \\
\hline $\mathrm{A} / \mathrm{G}$ ratio & 0.37 & 0.41 & 0.25 & 0.39 & 0.37 & 0.06 & 0.40 & 0.85 \\
\hline AST (U/L) & 250 & 217 & 207 & 220 & 206 & 20.3 & 0.55 & 0.19 \\
\hline ALT (U/L) & $6.81^{\mathrm{a}}$ & $3.43^{b}$ & $3.91^{b}$ & $1.97^{\mathrm{b}}$ & $2.41^{\mathrm{b}}$ & 0.90 & 0.01 & $<0.01$ \\
\hline Uric acid (mg/dL) & 5.65 & 6.13 & 6.83 & 5.28 & 5.50 & 0.52 & 0.26 & 0.51 \\
\hline Creatinine (mg/dL) & $0.08^{b}$ & $0.07^{b}$ & $0.08^{b}$ & $0.09^{\mathrm{ab}}$ & $0.11^{\mathrm{a}}$ & 0.01 & 0.04 & $<0.01$ \\
\hline $\begin{array}{l}\text { Antibody titer against NDV } \\
\left(\log _{2} \text { GMT) }\right.\end{array}$ & 1.20 & 3.33 & 1.67 & 2.67 & 3.00 & 0.72 & 0.17 & 0.23 \\
\hline
\end{tabular}

a,b Means in the same row with various letters indicate notable differences $(p<0.05)$

${ }^{1}$ Referes to analysis of variance (ANOVA)

${ }^{2}$ Referes to regression analysis

CONT: corn-soybean-based diet, FERM1; diet containing 1\%, FERM25: diet containing 2.5\%, FERM5: diet containing 5\%, FERM75: diet containing 7.5\% of the FERM, SE: standard error, LDL: low-density lipoprotein cholesterol, HDL: highdensity lipoprotein cholesterol, A/G ratio: albumin to globulin ratio, AST: aspartate aminotransferase, ALT: alanine aminotransferase, NDV: Newcastle disease vaccine, GMT: geometric mean titer

VIII: Selected bacteria populations in the intestine of the Indonesian indigenous crossbred chicken fed treatment diets

\begin{tabular}{|c|c|c|c|c|c|c|c|c|}
\hline \multirow{2}{*}{ Items (Log cfu/g) } & \multicolumn{5}{|c|}{ Dietary groups } & \multirow{2}{*}{ SE } & \multirow{2}{*}{$\begin{array}{l}P \text { value- } \\
\text { ANOVA }^{1}\end{array}$} & \multirow{2}{*}{$\begin{array}{c}P \text { value- } \\
\text { regression }\end{array}$} \\
\hline & CONT & FERM1 & FERM25 & FERM5 & FERM75 & & & \\
\hline \multicolumn{9}{|c|}{ Ileum } \\
\hline $\mathrm{LAB}$ & 11.2 & 11.4 & 11.2 & 11.3 & 11.1 & 0.14 & 0.62 & 0.30 \\
\hline Coliform & 9.08 & 9.27 & 8.76 & 9.41 & 9.05 & 0.21 & 0.26 & 0.91 \\
\hline Lactose negative-enterobacteria & 9.65 & 9.52 & 9.65 & 9.38 & 9.52 & 0.12 & 0.46 & 0.28 \\
\hline Enterobacteria & 9.77 & 9.80 & 9.76 & 9.77 & 9.74 & 0.04 & 0.84 & 0.48 \\
\hline \multicolumn{9}{|c|}{ Caecum } \\
\hline LAB & 11.6 & 11.7 & 11.6 & 11.7 & 11.6 & 0.07 & 0.69 & 0.88 \\
\hline Coliform & 8.99 & 8.97 & 8.97 & 9.16 & 8.87 & 0.22 & 0.93 & 0.93 \\
\hline Lactose negative-enterobacteria & 9.07 & 9.28 & 8.82 & 8.90 & 9.32 & 0.18 & 0.23 & 0.84 \\
\hline Enterobacteria & 9.37 & 9.47 & 9.23 & 9.36 & 9.56 & 0.16 & 0.68 & 0.61 \\
\hline
\end{tabular}

${ }^{1}$ Referes to analysis of variance (ANOVA)

${ }^{2}$ Referes to regression analysis

CONT: corn-soybean-based diet, FERM1; diet containing 1\%, FERM25: diet containing 2.5\%, FERM5: diet containing 5\%, FERM75: diet containing 7.5\% of the FERM, cfu: colony forming units, SE: standard error, LAB: lactic acid bacteria

The data on intestinal morphology of ICC are presented on Tab. IX. In duodenum, the elevated proportions of FERM linearly enhanced $(P<0.05)$ $\mathrm{CD}$, but did not change $(P>0.05) \mathrm{VH}$ and $\mathrm{VH}$ to $\mathrm{CD}$ ratio. At the level of $7.5 \%$, FERM reduced $(P<0.05)$
$\mathrm{CD}$ and enhanced $(P<0.05)$ the ratio of $\mathrm{VH}$ to $\mathrm{CD}$ of jejunum. In ileum, feeding 2.5\% FERM elevated $(P<0.05) \mathrm{VH}$ and $\mathrm{VH}$ to $\mathrm{CD}$ ratio, while regression test showed CD linearly enhanced $(P<0.05)$ with the enhanced proportion of FERM. 
IX: Morphology of the intestine of the Indonesian indigenous crossbred chicken fed treatment diets

\begin{tabular}{|c|c|c|c|c|c|c|c|c|}
\hline \multirow{2}{*}{ Items } & \multicolumn{5}{|c|}{ Dietary groups } & \multirow{2}{*}{ SE } & \multirow{2}{*}{$\begin{array}{l}P \text { value- } \\
\text { ANOVA }^{1}\end{array}$} & \multirow{2}{*}{$\begin{array}{l}P \text { value- } \\
\text { regression }\end{array}$} \\
\hline & CONT & FERM1 & FERM25 & FERM5 & FERM75 & & & \\
\hline \multicolumn{9}{|c|}{ Duodenum } \\
\hline $\mathrm{VH}(\mu \mathrm{m})$ & 1012 & 1130 & 1016 & 1004 & 996 & 58.4 & 0.47 & 0.40 \\
\hline $\mathrm{CD}(\mu \mathrm{m})$ & 218 & 253 & 235 & 244 & 303 & 21.8 & 0.10 & 0.01 \\
\hline $\mathrm{VH} / \mathrm{CD}$ & 4.72 & 4.67 & 4.51 & 4.16 & 3.37 & 0.39 & 0.11 & 0.94 \\
\hline \multicolumn{9}{|c|}{ Jejunum } \\
\hline $\mathrm{VH}(\mu \mathrm{m})$ & 930 & 1065 & 1011 & 935 & 1020 & 72.9 & 0.65 & 0.83 \\
\hline $\mathrm{CD}(\mu \mathrm{m})$ & $241^{\mathrm{ab}}$ & $273^{\mathrm{a}}$ & $209^{b c}$ & $231^{b}$ & $169^{c}$ & 13.6 & $<0.01$ & $<0.01$ \\
\hline $\mathrm{VH} / \mathrm{CD}$ & $3.93^{b}$ & $3.88^{\mathrm{b}}$ & $4.83^{b}$ & $4.22^{\mathrm{b}}$ & $6.14^{\mathrm{a}}$ & 0.40 & $<0.01$ & $<0.01$ \\
\hline \multicolumn{9}{|c|}{ Ileum } \\
\hline $\mathrm{VH}(\mu \mathrm{m})$ & $596^{\mathrm{b}}$ & $700^{\mathrm{b}}$ & $1289^{a}$ & $834^{b}$ & $806^{\mathrm{b}}$ & 152 & 0.03 & 0.32 \\
\hline $\mathrm{CD}(\mu \mathrm{m})$ & 159 & 199 & 176 & 213 & 233 & 19.7 & 0.10 & 0.01 \\
\hline $\mathrm{VH} / \mathrm{CD}$ & $3.92^{\mathrm{b}}$ & $3.62^{\mathrm{b}}$ & $7.21^{\mathrm{a}}$ & $4.07^{\mathrm{b}}$ & $3.81^{\mathrm{b}}$ & 0.82 & 0.02 & 0.94 \\
\hline
\end{tabular}

a,b,c Means in the same row with various letters indicate notable differences $(p<0.05)$

${ }^{1}$ Referes to analysis of variance (ANOVA)

${ }^{2}$ Referes to regression analysis

CONT: corn-soybean-based diet, FERM1; diet containing 1\%, FERM25: diet containing 2.5\%, FERM5: diet containing 5\%, FERM75: diet containing 7.5\% of the FERM, SE: standard error, VH: villus height, CD: crypt depth, VH/CD: villus height to crypt depth ratio

Carcass Yield and Commercial Cuts of Chickens

In general, diets possessed no influence $(P>0.05)$ on the carcass yield and commercial proportion of ICC (data not shown).

\section{DISCUSSION}

Fermentation is a conventional means to enhance the nutrient composition of feed components (Sugiharto and Ranjitkar, 2019). In agreement with the latter study, our present result noticed that fermentation with $C$. crassa enhanced the crude protein and remarkably lessened the fibre content of papaya leaf and seed meal. Our in vivo experiment pointed out that the elevated proportions of FERM linearly reduced cumulative feed consumption of chicks during week 1-4. Feeding papaya leaf or seed meal has formerly been associated with the reduced feed intake in broilers (Agboola et al., 2018; Bolu et al., 2009; Nideou et al., 2017). The reduced palatability as well as the substantial proportions of fibre and anti-nutritive components seemed to be responsible for the low intake in chicks fed papaya leaf or seed meal. Throughout the study period, the increased levels of FERM in diets linearly improved FCR values of ICC. Sugiharto and Ranjitkar (2019) have recently inferred that feeding fermented feed improved feed conversion in broilers. These workers further noticed that the improved nutritional and functional properties and the reduced antinutritional factors in the fermented feed may be responsible for the improved nutrient utilization in the chickens fed fermented feed. Other than being as phytogenic growth promoter, the use of FERM was also expected to partly reduce the proportion of soybean meal and meat bone meal as protein source in the rations, and thus alleviating the cost of feed. Indeed, feed cost per $\mathrm{kg}$ weight gain and income over feed cost linearly decreased and increased, respectively, following the increased dietary inclusion of FERM in the present study. This may suggest that FERM can be incorporated up to $7.5 \%$ in chicken diets to improve the economic performance of ICC.

The regression analysis demonstrated that the relative weight of proventriculus linearly reduced with the enhanced proportions of FERM in rations in this present study. Sugiharto and Ranjitkar (2019) pointed out that provision of fermented products resulted in improved nutrient digestibility in poultry. In other study, Widodo et al. (2018) reported that the improved protein digestibility due to xylanase administration was associated with the lowered relative weight of proventriculus and gizzard in broiler chickens. They further suggested that the reduced digestive organ weight was most likely attributed to the diminished enzyme production and physical functions of these organs due to the exogenous enzyme administration. Taking these studies into consideration, it was therefore interesting to speculate that feeding FERM seemed to improve protein digestibility attributing to the decreased relative weight of proventriculus of ICC. This assumption was supported by the linear improvement of FCR or feed efficiency in chicks with feeding FERM. Yet, this speculation should be 
accounted with careful since we did not determine the digestibility of protein in the current trial.

In this experiment, the values of hemoglobin, erythrocytes and haematocrit linearly reduced with the enhanced proportions of FERM in chicken feeds. Considering the role of these blood components in transporting oxygens, the linear reduction of hemoglobin and erythrocytes may be attributed to the impaired oxygens transport capacity of blood. Yet, the latter condition seemed not to be the case in our study as the linear reduction in hemoglobin and erythrocytes was not accompanied by the reduction in growth rate of chickens. Indeed, the levels of hemoglobin, erythrocytes and haematocrit in this study were within the normal ranges (Sugiharto et al., 2018a) and had therefore no detrimental effect on the performance of chicks. The MCH values were higher in birds fed on FERM1 and FERM25 than that in control birds. Huff et al. (2008) noted that the decreased level of MCH may be associated with stress condition in broilers. In this experiment, it was difficult to relate the $\mathrm{MCH}$ levels to FERM as the MCH levels were not linearly dependent on dietary FERM levels. Heterophils is leukocytes fraction that have been attributed to the defence against bacteria that may jeopardize the chickens, and that the increased heterophils counts may indicate the bacterial infections/inflammation in chickens (Hidanah et al., 2018). In this current work, ANOVA test showed that dietary inclusion of FERM significantly influenced the counts of heterophils in the circulatory system of chickens. However, the influence had no certain pattern as there was no notable difference in the heterophils counts between the chicks fed fermented feed and the control diet. Also, the regression test showed no effect of feeding the graded levels of FERM on the numbers of heterophils. Across the treatments, the values of heterophils were within the normal range, and therefore it was not easy to assess the health status of the chickens in this trial based on the heterophils counts. Indeed, Samour (2015) documented that the counts of heterophils in healthy and normal chickens are 0.5 to $7.6 \times 10^{3} / \mu \mathrm{L}$. The thrombocytes values enhanced with the elevated proportions of FERM in chicken feeds. Besides essential in thrombosis and haemostasis, thrombocytes have recently been known to exhibit a crucial functions in the immune reactions of animals (Ferdous and Scott, 2015). In this respect, feeding FERM seemed to be beneficial in improving the immune functions of the ICC. In addition to the effect of feeding fermented feed in improving the immune responses (Sugiharto and Ranjitkar, 2019), the presences of some bioactive compounds in papaya leaf and seed such as saponin (Ojiako et al., 2019) may also be responsible for the improved immune response of the chickens.

In this trial, inclusion of FERM particularly at $2.5 \%$ resulted in higher HDL to LDL ratio as compared to that of control chicken. Apart from the ANOVA test, the regression analysis showed that the HDL to LDL ratio enhanced with the elevated proportions of FERM. In concurrence to our study, Santoso et al. (2018) demonstrated that feeding fermented Sauropus androgynus plus bay leaf increased the HDL to LDL ratio in broiler chickens. They further inferred that the contents of flavonoids and glycosides in the fermented herbs may account to the enhanced and reduced concentrations of HDL and LDL in the plasma of broiler strains, respectively. The elevated serum levels of AST and ALT denote the liver dysfunction (Rocha et al., 2013). Dietary incorporation of FERM resulted in reduced levels of ALT in the serum than that in control chickens. Bolu et al. (2009) showed the higher levels of AST and ALT with feeding of papaya seed meal to broilers. Possibly, fermentation eliminated the harmful properties in papaya leaf and seed such as toxins that can impair the liver functions (Sugiharto and Ranjitkar, 2019). Results in our current study showed that FERM75 had higher serum level of creatinine than that of other dietary groups. Previously, Bolu et al. (2009) documented that provision of dried papaya seed elevated the serum concentration of creatinine in broilers, but data on the effect of papaya leaf on serum creatinine are not available in the literature so far. Considering that higher level of creatinine may indicate the renal dysfunction and/or higher breakdown of tissue protein, the increased level of creatinine may negatively affect the health and productivity of the chickens. Owing to this fact, the FERM may be safely incorporated in ICC diets at the maximum level of 5\% as the higher inclusion level may impair the renal functions of the chickens. This inference should, however, be noted with careful as the serum creatinine level of chicks in this study was still in the normal range. Values of $0.20 \mathrm{mg} / \mathrm{dL}$ (Albokhadaim et al., 2012) and 0.21 to $0.25 \mathrm{mg} / \mathrm{dL}$ (Polat et al., 2011) were reported. In this work, the inclusion of the FERM up to $7.5 \%$ did also not compromise the growth rate of ICC compared to control group.

The antibacterial activities of papaya leaf and seed have been demonstrated by many investigators (Baskaran et al., 2012; Peter et al., 2014). Also, the antibacterial effect of the fermented feed have been revealed on chicken intestine (Sugiharto and Ranjitkar, 2019). In contrast to these earlier studies, data in our current work did not exhibit any antibacterial activity of the FERM on the bacterial counts in the ileum and caeca of ICC. The differences in the nature of raw papaya leaf and seed, types of chickens, dietary compositions and also the condition during the study may elucidate the variations between our data and other workers.

In contrast to jejunum, the linear increase in $C D$ was seen in duodenal and ileal segments of birds with the elevated proportions of FERM. In general, the enhanced $\mathrm{VH}$ and $\mathrm{VH} / \mathrm{CD}$ ratio or the reduced $\mathrm{CD}$ are associated with the improved digestive and 
absorptive process in chicks (Pluske et al., 1996). Given that feeding FERM did not diminish $\mathrm{VH}$ and $\mathrm{VH} / \mathrm{CD}$ ratio, the increased $\mathrm{CD}$ in duodenal and ileal segments in this present study seemed therefore not to affect the nutrient digestion and absorption of chicks. This was supported by the fact that feeding FERM did not affect the growth rate, and even improved the FCR of chickens. Indeed, at the level of 7.5\%, FERM reduced CD and increased VH/CD ratio in jejunum. In ileum, the incorporation of $2.5 \%$ FERM increased VH and VH/CD ratio. Previously, Naji et al. (2016) reported that fermented product was related to the increased $\mathrm{VH}$ and $\mathrm{VH}$ to $\mathrm{CD}$ ratio throughout the intestinal segments of broilers. According to Sugiharto and Ranjitkar (2019), the increased counts of LAB and small peptides in the intestine and the lower contents of toxins, antigenic components and antinutritional factors in the fermented feed may favourably improve the intestinal morphology of chickens.

The current treatments possessed no influence on the carcass traits of chickens. In agreement, earlier study demonstrated that feeding fermented cassava pulp resulted in the absent influence on the carcass weight and commercial cuts of broilers (Khempaka et al., 2014). Also, dietary incorporation of fermented pineapple peel resulted in absent influence on the carcass characteristics of broiler strains (Heryandi et al., 2018). In respect to papaya leaf and seed, feeding papaya leaf (Oloruntola et al., 2018), seed (Bolu et al., 2009) or the blend of papaya leaf and seed (Oloruntola, 2019) did not influence the carcass characteristics of broiler chickens.

\section{CONCLUSION}

Dietary incorporation of FERM improved economic performance, immune responses, physiological condition and intestinal morphology of ICC.

Acknowledgements

The project was sponsored by Diponegoro University, grant number 329-88/UN7.P4.3/PP/2019. Tri A. Sartono, Diyyani, Bellinda, Ilham Muhammad and Adyaksa are acknowledged for his assistance during the in vivo trial.

\section{REFERENCES}

ADESUYI, A. O. and IPINMOROTI, K. O. 2011. The nutritional and functional properties of the seed flour of three varieties of Carica papaya. Current Research in Chemistry, 3(1): 70-75.

AGBOOLA, B. E., OLOGHOBO, A. D., ADEJUMO, I. O. and ADEYEMO, G. O. 2018. Response of broiler chickens to Carica papaya and Talinium triangulare leaf meal under normal and subnormal diets. Annual Research and Review in Biology, 23(4): 1-7.

ALBOKHADAIM, I., ALTHNAIAN, T. and EL-BAHR, S. 2012. Investigation of selected biochemical parameters of local chickens with different age and sex in Al-ahsa, Saudi Arabia. Pakistan Journal of Biological Science, 15(17): 827-832.

AOAC. 1995. Official methods of analysis of the Association of Analytical Chemists. $16^{\text {th }}$ Edition. Washington DC, USA: AOAC.

BASKARAN, C., RATHA BAI, V., VELU, S. and KUMARAN, K. 2012. The efficacy of Carica papaya leaf extract on some bacterial and a fungal strain by well diffusion method. Asian Pacific Journal of Tropical Disease, 2(Supplement 2): 658-662.

BOLTON, W. 1967. Poultry nutrition. MAFF Bulletin No. 174. London: HMSO.

BOLU, S. A. O., SOLA-OJO, F. E., OLORUNSANYA, O. A. and IDRIS, K. 2009. Effect of graded levels of dried pawpaw (Carica papaya) seed on the performance, haematology, serum biochemistry and carcass evaluation of chicken broilers. International Journal of Poultry Science, 8(9): 905-909.

FERDOUS, F. and SCOTT, T. R. 2015. A comparative examination of thrombocyte/platelet immunity. Immunology Letters, 163(1): 32-39.

FREMPONG, N. S., NORTEY, T. N. N., PAULK, C. and STARK, C. R. 2019. Evaluating the Effect of replacing fish meal in broiler diets with either Soybean meal or poultry by-product Meal on Broiler Performance and total feed cost per kilogram of gain. Journal of Applied Poultry Research, 28(4): 912-918.

HALIM, S. Z., ABDULLAH, N. R., AFZAN, A., ABDUL RASHID, B. A., JANTAN, I. and ISMAIL, Z. 2011. Acute toxicity study of Carica papaya leaf extract in Sprague Dawley rats. Journal of Medicinal Plant Research, 5(10): 1867-1872.

HERYANDI, Y., ADRIZAL, NINGSIH, N. and MAHATA, M. E. 2018. Carcass characteristics and organ development of broilers fed fermented pineapple peel [Ananas comosus (L.) Merr] waste using a local microorganism solution derived from bamboo sprouts. International Journal of Poultry Science, 17(5): 229-233. 
HIDANAH, S., SABDONINGRUM, E. K., WAHJUNI, R. S. and CHUSNIATI, S. 2018. Effects of meniran (Phyllanthus niruri L.) administration on leukocyte profile of broiler chickens infected with Mycoplasma gallisepticum. Veterinary World, 11(6): 834-839.

HUFF, G. R., HUFF, W. E., RATH, N. C., ANTHONY, N. B. and NESTOR, K. E. 2008. Effects of Escherichia coli challenge and transport stress on hematology and serum chemistry values of three genetic lines of turkeys. Poultry Science, 87(11): 2234-2241.

JEONG, J. -S. and KIM I. -H. 2015. Effect of fermented medicinal plants (Gynura Procumbens, Rehmannia Glutinosa, Scutellaria Baicalensis) as alternative performance enhancers in broilers. Journal of Poultry Science, 52(2): 119-126.

KHEMPAKA, S., THONGKRATOK, R., OKRATHOK, S. and MOLEE, W. 2014. An evaluation of cassava pulp feedstuff fermented with $A$. oryzae, on growth performance, nutrient digestibility and carcass quality of broilers. Journal of Poultry Science, 51(1): 71-79.

MAISARAH, A. M., NURUL AMIRA, B., ASMAH, R. and FAUZIAH, O. 2013. Antioxidant analysis of different parts of Carica papaya. International Food Research Journal, 20(3): 1043-1048.

MENESES, C., SILVA, B., MEDEIROS, B., SERRATO, R. and JOHNSTON-MONJE, D. 2016. A metagenomic advance for the cloning and characterization of a cellulase from red rice crop residues. Molecules, 21(7): 831-842.

NAJI, S. A., AL-ZAMILI, I. F. B., HASAN, JAWAD, S. A. and AL-GHARAWI, J. K. M. 2016. The effects of fermented feed on broiler production and intestinal morphology. Pertanika Journal of Tropical Agricultural Science, 39(4): 597-607.

NIDEOU, D., SOEDJI, K., TETEH, A., DECUYPERE, E., GBEASSOR, M. and TONA, K. 2017. Effect of Carica papaya seeds on gastro-intestinal parasites of pullet and production parameter. International Journal of Probiotics and Prebiotics, 12(2): 89-95.

OJIAKO, C. M., OKOYE, E. I., OLI, A. N., IKE, C. J., ESIMONE, C. O. and ATTAMA, A. A. 2019. Preliminary studies on the formulation of immune stimulating complexes using saponin from Carica papaya leaves. Heliyon, 5(6): e01962.

OLORUNTOLA, O.D. 2019. Effect of pawpaw leafand seed meal composite mix dietary supplementation on haematological indices, carcass traits and histological studies of broiler chicken. Bulletin of the National Research Centre, 43: 129.

OLORUNTOLA, O. D., AYODELE, S. O. and OLORUNTOLA, D. A. 2018. Effect of pawpaw (Carica papaya) leaf meal and dietary enzymes on broiler performance, digestibility, carcass and blood composition. Revue d'élevage et de médecine vétérinaire des pays tropicaux, 71(3): 121-129.

ONYIMONYI, A. E. and ERNEST O. 2009. An assessment of pawpaw leaf meal as protein ingredient for finishing broiler. International Journal of Poultry Science, 8(10): 995-998.

PARK, J. H., SONG, T. H. and KIM, I. 2016. Egg production, egg quality, and cecal microbial populations of layers fed diets supplemented with fermented phytogenic feed additive. Turkish Journal of Veterinary and Animal Sciences, 40: 660-666.

PETER, J. K., KUMAR, Y., PANDEY, P. and MASIH, H. 2014. Antibacterial activity of seed and leaf extract of Carica Papaya var. Pusa dwarf Linn. IOSR Journal of Pharmacy and Biological Sciences, 9(2): 29-37.

PLUSKE, J. R., TOMPSON, M. J., ATWOOD, C. S., BIRD, P. H., WILLIAMS, I. H. and HARTMANN, P. E. 1996. Maintenance of villus height and crypt depth, and enhancement of disaccharide digestion and monosaccharide absorption, in piglets fed on cows' whole milk after weaning. British Journal of Nutrition, 76(3): 409-422.

POLAT, U., YESILBAG, D. and EREN, M. 2011. Serum biochemical profile of broiler chickens fed diets containing rosemary and rosemary volatile oil. Journal of Biological \& Environmental Sciences, 5(13): 23-30.

QIAO, H., SONG, Y., SHI, H. and BIAN, C. 2018. Fermented Astragalus in diet altered the composition of fecal microbiota in broiler chickens. AMB Express, 8: 151.

ROCHA, T. M., ANDRADE, M. A., GONZALES, E., STRINGHINI, J. H., SANTANA, E. S., PÔRTO, R. N. G. and MINAFRA-REZENDE, C. S. 2013. Liver function and bacteriology of organs in broiler inoculated with nalidixic acid-resistant Salmonella Typhimurium and treated with organic acids. Italian Journal of Animal Science, 12: e55.

SAMOUR, J. 2015. Diagnostic value of hematology in clinical avian medicine. Volume II. Spix Publishing.

SANTOSO, U., FENITA, Y. and KUSUSIYAH. 2018. The Effect of fermented Sauropus androgynus plus bay leaf inclusion on the hematologic and lipid profiles of female broiler chickens. International Journal of Poultry Science, 17(9): 410-417.

SUGIHARTO, S. and RANJITKAR, S. 2019. Recent advances in fermented feeds towards improved broiler chicken performance, gastrointestinal tract microecology and immune responses: A review. Animal Nutrition, 5(1): 1-10. 
SUGIHARTO, S., YUDIARTI, T., ISROLI, I., WIDIASTUTI, E. and WAHYUNI, H. I. 2018a. Hematological parameters and selected intestinal microbiota populations in the ICC fed basal diet supplemented with multi-strain probiotic preparation in combination with vitamins and minerals. Veterinary World, 11(6): 874-882.

SUGIHARTO, S., ISROLI, I., YUDIARTI, T., WIDIASTUTI, E., WAHYUNI, H. I. and SARTONO, T. A. $2018 \mathrm{~b}$. Effect of two-step fermentation by Chrysonilia crassa and Bacillus subtilis on nutritional values and antioxidative properties of agro-industrial by-products as poultry feed ingredients. Journal of Advanced Veterinary and Animal Research, 5(4): 472-480.

TUNÇ, M. A., YILDIRIM, S. and YORÜK, M. A. 2019. Effects of tarragon (Artemisia dracunculus) powder on broiler performance parameters and histopathology of internal organs. Austral Journal of Veterinary Sciences, 51(3): 113-118.

VILLEGAS, P. 1987. Avian virus diseases laboratory manual. Athens, Georgia, USA: College of Veterinary Medicine. University of Georgia

WIDODO, A. E., NOLAN, J. V., AKTER, M., O'NEILL, H. M. and IJI, P. A. 2018. Response of broiler chickens to triticale-based diets supplemented with microbial enzymes (1. Growth and intestinal function). Poultry Science Journal, 6(1): 25-40.

YANG, C., CHOWDHURY, M. A. K., HOU, Y. and GONG, J. 2015. Phytogenic compounds as alternatives to in-feed antibiotics: potentials and challenges in application. Pathogens, 4(1): 137-15.

Contact information

Sugiharto Sugiharto: sgh_undip@yahoo.co.id 